\title{
IJBF INTEREST RATE AND FOREIGN EXCHANGE RISK EXPOSURES OF AUSTRALIAN BANKS: A NOTE
}

\author{
Abul F. M. Shamsuddin \\ University of Newcastle, Australia
}

\begin{abstract}
The abolition of most government controls over the Australian financial system in the 1980s, the advent of a flexible exchange rate regime in 1983 and the globalisation of the financial system in the 1990s have created new opportunities for Australian banks but exposed them to new sources of risk. This study estimates systematic risk exposure of publicly listed Australian banks with respect to market, interest rate and foreign exchange rate using a GARCH-inMean model. Not surprisingly, the results suggest that nearly all banks exhibit varying degrees of market risk exposure. However, stock returns of large banks are highly sensitive to interest rate changes, while most small banks are almost immune to both interest and exchange rate changes.
\end{abstract}

Keywords: Interest rate risk, Foreign exchange rate risk, Australian Banks JEL Classification: G12, G21

\section{Introduction}

The traditional focus of the literature on modelling bank stock returns is on the interest rate risk. This emphasis on interest rate exposure is primarily attributed to banks' historical reliance on net interest income as the primary source of profits. However, the removal of most government controls over the Australian banking system in the 1980s and the introduction of a flexible exchange rate regime in 1983 have produced new opportunities for Australian banks but exposed them to new risk factors. ${ }^{1}$ In this study, we estimate the sensitivity bank stock returns with respect to these risk factors.

\footnotetext{
Australian banks were subject to three forms of regulatory controls, following the Second World War: directing bank loans to specific sectors, regulating the quantity of bank loans or deposits and controlling interest rates for deposits and loans. By 1991 all of these quantitative controls were removed, which increased competition in the banking industry but also relaxed the upper limit on bank risk-taking. Thus, in recent years regulatory authorities have increased their emphasis on prudential supervision to limit risk-exposure of financial institutions and ultimately, to protect depositors' funds and maintain the stability of the financial system.
} 
The fundamental model of valuation suggests that a bank's stock price depends on its discounted stream of expected cash flows, which in turn is partly determined by how effectively the bank manages its risk exposures. Total risk tolerated by a bank's shareholders results from the bank's two unique intermediation functions. First, the bank performs the brokerage function, acting as an agent for households and businesses in providing financial products and transaction services. Second, the bank performs the traditional asset transformation function by issuing financial claims that are more attractive to savers than the claims directly issued by corporations. In conducting these two core functions, the bank faces a range of risks, including market risk, interest rate risk and foreign exchange risk. These risk factors influence the bank's expected stream of cash flows and ultimately, returns on bank stocks. Thus, the sensitivity of bank stock returns with respect to these risk factors reveals market's perception of risk exposure of banks.

Prior to the adoption of a floating exchange rate in December 1983, the Australian dollar was overvalued. Between January 1984 and December 2001 the Australian dollar depreciated against the US dollar by about 44 percent. Since 2002 the Australian dollar has appreciated significantly against the US dollar primarily due to its spectacular economic performance, primarily fueled by the global resources boom. The post-deregulation period also witnessed highly volatile interest rates, ranging from 18 percent to 4.25 percent. The high volatility in interest rates and foreign exchange rates was accompanied by an average return on Australian bank stocks of over 10 percent per annum. These stylized facts seem to indicate that in general Australian banks have been effective in managing their risk exposures in the post deregulation period.

This paper investigates risk exposures of ten publicly listed Australian banks over the post-deregulation period, from 1994 to 2007 . More specifically, the sensitivity of bank stock returns with respect to market, interest rate and foreign exchange rate is evaluated, taking into account the potential trade-off between bank stock return and its forecast volatility. The remainder of this paper is organized as follows. The second section reviews the literature. The empirical model is presented in section 3 and the corresponding results are interpreted in section 4 . The final section presents some concluding remarks.

\section{Literature Review}

From the vast empirical literature on risk exposures of commercial banks, this section puts forward a review some representative Australian and international studies, which evaluated risk exposure based on the sensitivity of bank stock returns to interest and exchange rates and market risk factors.

There have been some attempts in evaluating risk exposures of Australian banks since the early 1990s. Harper and Scheit (1992) investigated the impact of financial deregulation on the riskiness of three major Australian banks: ANZ

Bank, National Australia Bank and Westpac Banking Corporation. Using monthly data from January 1974 to December 1989, they demonstrated that 
financial deregulation did not influence the systematic or market risk exposures of these banks or of the banking industry as a whole. They did not consider other sources of risks such as the interest rate or foreign exchange rate risks.

Daugaard and Valentine (1993), however considered other sources of risks. They investigated the sensitivity of bank share prices to changes in variables such as interest rates, exchange rates, a market risk factor (Dow Jones US Banking - Money Centre Index) and bank profits. Using quarterly data for the period, 1983 to 1991, they demonstrated that an appreciation of the Australian dollar significantly increased bank share prices, measured by the ASX banking and finance price index. This study has some shortcomings. First, the scope of their study was limited to modeling the composite stock price index of the banking and finance industry rather than stock prices of individual banks or the price index for the banking industry alone. Second, their sample includes a major structural break - the introduction of the floating exchange rate regime in December 1983. No attempt was made to investigate the impact of this structural change on the exchange rate sensitivity of bank share prices. ${ }^{2}$ Third, the use of the Dow Jones US Banking - Money Centre Index as a proxy for the Australian market portfolio is incompatible with the Capital Asset Pricing Model.

Iorio and Faff (2000) examined the potential asymmetric response of industry stock index returns to the foreign exchange rate. They considered 24 Australian industries, including the banking industry but ignored the interest rate risk factor. ${ }^{3}$ Using monthly data for the period 1988 to 1996, they found that the foreign exchange risk was irrelevant in pricing bank stocks. In daily data, however, the foreign exchange risk was relevant only when daily appreciation of the Australian dollar was at least 1 percent. Thus, their results indicate that the banking industry as a whole manage the foreign exchange risk effectively, making expected cash flows insensitive to exchange rate fluctuations at least in the medium- to long-term. In a subsequent study on bank risk exposures in ten markets within the Asia-Pacific region, Yong and Faff (2007) observed that the Australian bank stock portfolio was exposed to market and long-term interest rate risks, but not foreign exchange risk.

Some US and Canadian studies, however, incorporated market, interest rate and exchange rate risk factors in modeling bank stock returns. For example, Choi, et al. (1992) used monthly data over the period January 1975 to December 1987 for the 48 largest US commercial banks. They observed that bank stock returns respond negatively to interest rates and the impact of the exchange rate depends on the banks' net position in foreign currencies. Their results confirmed that a depreciation of foreign currencies negatively influenced bank stock returns

2 Indeed, a later study (Dennis and Jeffrey, 2002) documented significant structural changes in Australian bank risk over the period 1981 to 1993. These changes coincided with the deregulatory initiative in the early 1980s, flotation of the Australian dollar and the implementation of Basel accord.

3 However, in an earlier study, Faff and Howard (1999) estimated market and interest rate risk exposures of Australian financial sector companies at the portfolio level. 
prior to October 1979, when banks had a positive net position in major foreign currencies. After that date, banks' foreign currency position changed from a positive net position to a negative net position and a depreciation of foreign currency increased bank stock returns. Thus, the exchange rate was an important risk factor for US bank stock returns. A comparable study for the six largest Canadian chartered banks was conducted by Atindéhou and Gueyie (2001). They observed that in general a depreciation of foreign currencies against the Canadian dollar increased bank stock returns. This result is consistent with the negative foreign currency position of Canadian banks over their sample period.

A few studies examined risk exposures of banks using models from the GARCH family. The first attempt in this area is a study by Elyasiani and Mansur (1998) on interest risk exposures of the US banks. They found that both interest rate and interest rate volatility influence mean as well as the conditional volatility of bank stock returns. Ryan and Worthington (2004) replicated their study in the context of Australia, taking into account foreign exchange rate as an additional source of risk. However, these studies examined risk exposures at the industry or portfolio level, not at the individual bank level. Our study is a novel attempt in evaluating risk exposures of individual Australian banks within a GARCH framework.

\section{Empirical Model}

A multi-index model of bank stock returns is used in this paper with return on the market portfolio, interest rate, foreign exchange rate and conditional volatility as indexes. Conditional variance of bank stock returns is generated by a GARCH $(1,1)$ process and a lagged interest volatility term. The latter explanatory factor was proposed by a US study on bank stock returns (Elyasiani and Mansur, 1998) to capture incremental information on macroeconomic volatility that is contained in the second moment of the distribution of interest rates. In this paper, the following $\operatorname{GARCH}(1,1)$-in-Mean model is used for empirical investigation:

$$
\begin{aligned}
& R_{j, t}=\beta_{0}+\beta_{1} R_{m, t}+\beta_{2} \Delta y_{t}+\beta_{3} E_{t}+\gamma \sqrt{h_{j, t}}+\varepsilon_{j, t} \\
& h_{j, t}=\alpha_{0}+\alpha_{1} \varepsilon_{j, t-1}^{2}+\alpha_{2} h_{j, t-1}+\lambda\left(C I V_{t-1}\right) \\
& \varepsilon_{j, t} \mid \Omega \sim N\left(0, h_{j, t}\right)
\end{aligned}
$$

In the mean equation (1), $R_{j}$ is the rate of return on bank stock or bank portfolio $\mathrm{j}, R_{m}$ is the rate of return on the market portfolio; $\Delta \mathrm{y}$ is the change in the long term interest rate; $\mathrm{E}$ is the rate of change in the value of the Australian dollar (expressed in terms of USD); $\sqrt{h_{j}}$ is the conditional standard deviation of bank stock returns; and $\varepsilon_{j}$ is a serially uncorrelated random error term. Conditional 
variance, $h_{j, t,}$ is determined by a constant or unconditional variance, $\alpha_{0}$, and the weighted sum of three components - last period's news about volatility or squared innovation, $\varepsilon_{j, t-1}^{2}$, last period's conditional variance, $h_{j, t}$, and last period's conditional interest rate volatility, $C I V_{t-1}$. The conditional interest rate volatility was estimated from a $\operatorname{GARCH}(1,1)$ model.

This study considers ten financial firms that are regarded as banks under the Global Industry Classification Standard and currently listed on the Australian Stock Exchange. These are: ANZ Banking Group Ltd, Bendigo Bank Limited, Bank of Queensland Limited, Commonwealth Bank of Australia, National Australia Bank Limited, The Rock Building Society Limited, St. George Bank Limited, Suncorp- Metway Limited, Wide Bay Australia Ltd and Westpac Banking Corporation. The following null hypotheses are tested for the individual bank stocks as well as for the portfolio of bank stocks:

$\mathrm{H}_{1}$ : $\quad$ Bank stock return is invariant to market conditions: $\beta_{1}=0$ Under this hypothesis, banks are not exposed to systematic risk.

$\mathrm{H}_{2}$ : The conditional interest rate volatility has no influence on the conditional stock return volatility: $\lambda=0$. In this case, the conditional stock return volatility follows a pure $\operatorname{GARCH}(1,1)$ process without any exogenous macroeconomic variable.

$\mathrm{H}_{3}$ : Neither the change in interest rate nor the interest rate volatility influences the stock return generating process: $\beta_{2}=\lambda=0$. Under this hypothesis, the bank has no net exposure to interest rate risk.

$\mathrm{H}_{4}$ : Bank stock return is insensitive to the change in the foreign exchange rate: $\beta_{3}=0$. Put differently, the bank has no net exposure to foreign exchange rate risk.

$\mathrm{H}_{5}:$ Conditional volatility is not a relevant factor in pricing bank stocks: $\gamma=0$. Under this null hypothesis, there is no trade-off between bank stock return and its conditional volatility.

$\mathrm{H}_{6}$ : Volatility is time invariant: $\alpha 1=\alpha 2=\lambda=0$.

\section{Data and Results}

This study uses weekly data from 26 September 1994 to 4 June 2007. All data are retrieved from Datastream. Weekly returns on individual bank stocks are calculated from the total return index (RI) series, created by Datastream for individual equities. This series is suitable for calculating holding period total return as it captures both the price change and the dividend income components. The rate of return on an individual bank stock, $R_{j}$ is calculated as 100 times logarithm of return index relatives. The return on the bank stock 
portfolio is market capitalisation weighted returns on individual bank stocks. The Datastream total stock market index for Australia is used as a proxy for the market portfolio, and total return is calculated as 100 times logarithm of the relevant return index relatives We use the weekly change in the 10-year Treasury bond yield as a proxy for interest rate change, $\Delta y$. The rate of change in the value of the Australian dollar against the US dollar (E) is measured as 100 times log exchange rate relatives.

The results for the market capitalization weighted bank portfolio and individual banks are presented in Table 1. The banking sector as a whole is exposed to market risk but the beta coefficient is less than unity and statistically significant. The results for individual banks show that the four major banks are more sensitive to the change in market conditions than that of small banks.

Interest rate risk arises from mis-matching of maturity of a bank's assets and liabilities. Any change in the interest rate has the potential to influence a bank's net interest income as well as market values of its assets and liabilities, which in turn is reflected in bank stock price changes. The model used in this paper allows both the interest rate and the conditional volatility of the interest rate to influence bank stock risk and return. For the banking sector as a whole, the mean equation shows that one percentage point increase in the interest rate leads to 1.68 percentage point decrease in return. Interestingly, the interest sensitivity coefficient is negative for all banks but statistically significant for only five large banks: National Australia Bank Limited, Commonwealth Bank of Australia, ANZ Banking Group, Westpac Banking Corporation and St. George Bank. As noted earlier, we estimate the conditional interest rate volatility (CIV) using a GARCH $(1,1)$ model without any exogenous variables and then use the lagged CIV variable in the second moment equation for bank stock returns. It is argued that the interest rate volatility conveys incremental information regarding macro economic conditions and may influence the volatility of bank stock returns. This is indeed the case for eight out of ten banks considered in this study. The coefficient of the CIV variable is negative and highly significant for the bank portfolio.

\footnotetext{
4 Transaction exposure measures the variability of the bank's (contractually specified) future cash transactions resulting from exchange rate fluctuations. This exposure arises from a bank's foreign currency denominated payables and receivables. The second dimension of foreign exchange risk is translation exposure, which arises from conversion of foreign currency denominated assets and liabilities into domestic currency. Although this exposure leads to unrealized gains and losses, it might affect a bank's expected cash flows and hence, its share price. Finally, operating exposure measures the long-term impact of exchange rate changes on the bank's profitability. For example, exchange rate fluctuations may influence the bank's cash flows by changing the cost of a bank's inputs and revenue earned from its financial products. Unlike translation and transaction exposure, operating exposure is difficult to quantify and can not be eliminated using market based hedging instruments.
} 
Next we turn to foreign exchange risk, which has three dimensions: transaction exposure, translation exposure and operating exposure. These underlying exposures determine the degree of sensitivity of bank stock returns with respect to changes in foreign exchange rates. The exchange rate parameter is positive and highly significant for the bank portfolio, indicating that an appreciation of the Australian dollar exerts positive influence on bank stock returns. At the individual bank level, this empirical assertion only holds for ANZ bank and Bank of Queensland. The results suggest that stock returns for most banks in Australia are not sensitive to the change in the exchange rate. Perhaps, these banks adequately mange their foreign exchange risk exposure.

The GARCH-in-Mean model also allows us to examine the potential tradeoff between bank stock returns and its conditional volatility, which has been approximated by the parameter, $\gamma$. This coefficient is statistically insignificant at the 5 percent level in all but the model for ANZ bank. We observe a positive tradeoff between risk and return for ANZ bank, which implies that the conditional volatility is priced. However, for the banking sector as a whole the conditional volatility is irrelevant in pricing bank stocks.

Finally, a Wald test suggests that the volatility of bank stock return is time variant. That is, the null hypothesis of $\alpha_{1}=\alpha_{2}=\lambda=0$ can be rejected at the 5 percent level of significance.

\section{Conclusion}

This study contributes to the Australian literature on bank risk in two important dimensions. First, this paper focuses on risk exposure of individual banks in the post-deregulation period, when Australian banks were exposed to new opportunities as well as increased risk. Second, this study allows both the level and the volatility of the interest rate to influence the distribution of individual bank stock returns. In general, the results suggest that large banks are highly sensitive to interest rate changes. Most small banks are immune to both interest and foreign exchange rate changes. We observe time variation in the volatility of bank stock returns but no significant trade-off between return and the conditional volatility for bank stocks. Further research can be directed to examine factors driving cross-sectional variation in risk exposure of Australian banks.

Author statement: Abul Shamsuddin is a professor at the Newcastle Graduate School of Business, The University of Newcastle, Callaghan, NSW 2308, Australia. Tel: +61-2-4921 8971; fax: +61-2-4921 7398, E-Mail: Abul. Shamsuddin@newcastle.edu.au. The author acknowledges financial support for this study from a New Staff Grant. An earlier version of the paper was presented at the Fourth International Conference on Banking and Finance 2008, Langkawi Island, Malaysia. The author acknowledges with thanks the editorial review comments as responded in the revised version of this paper. 


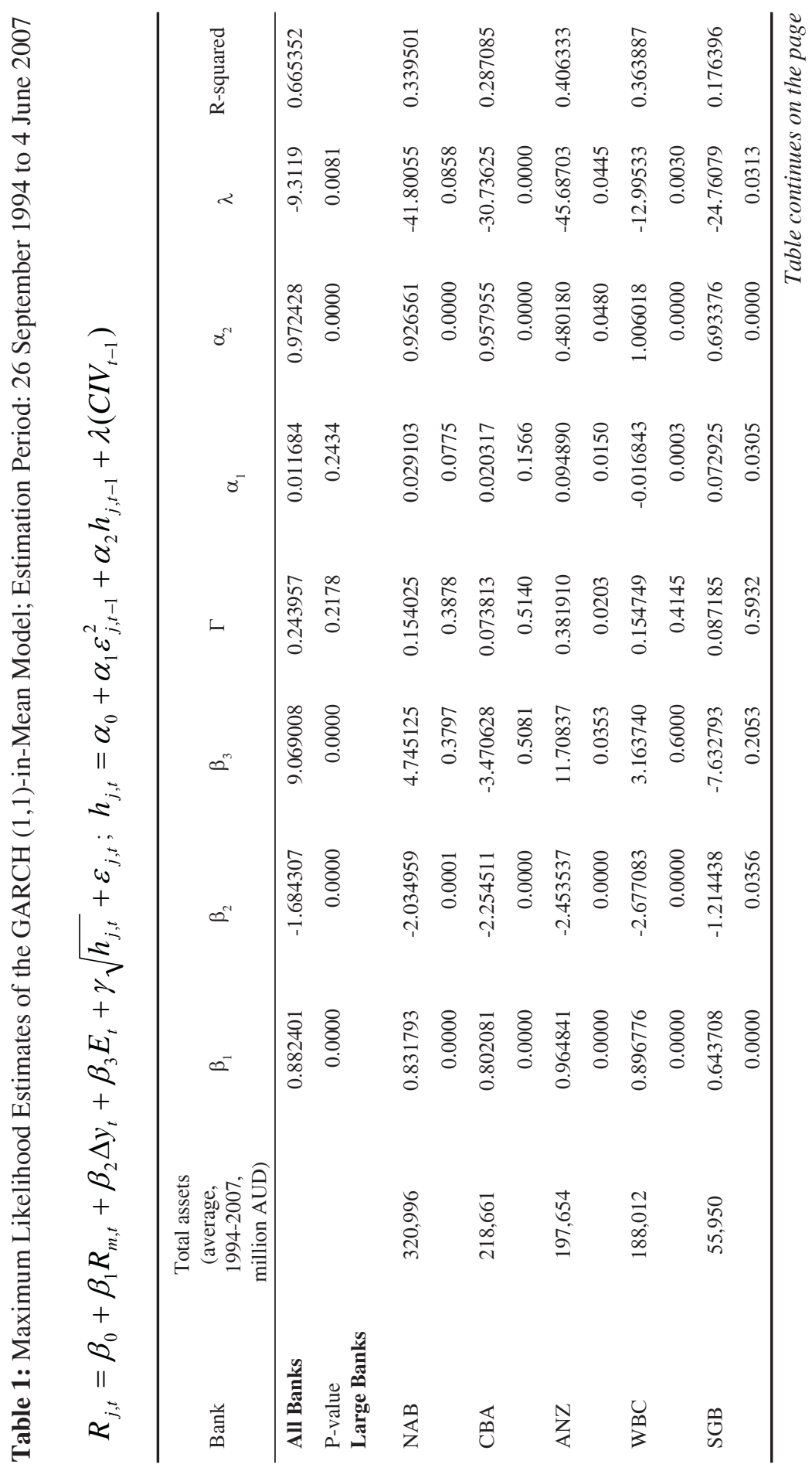




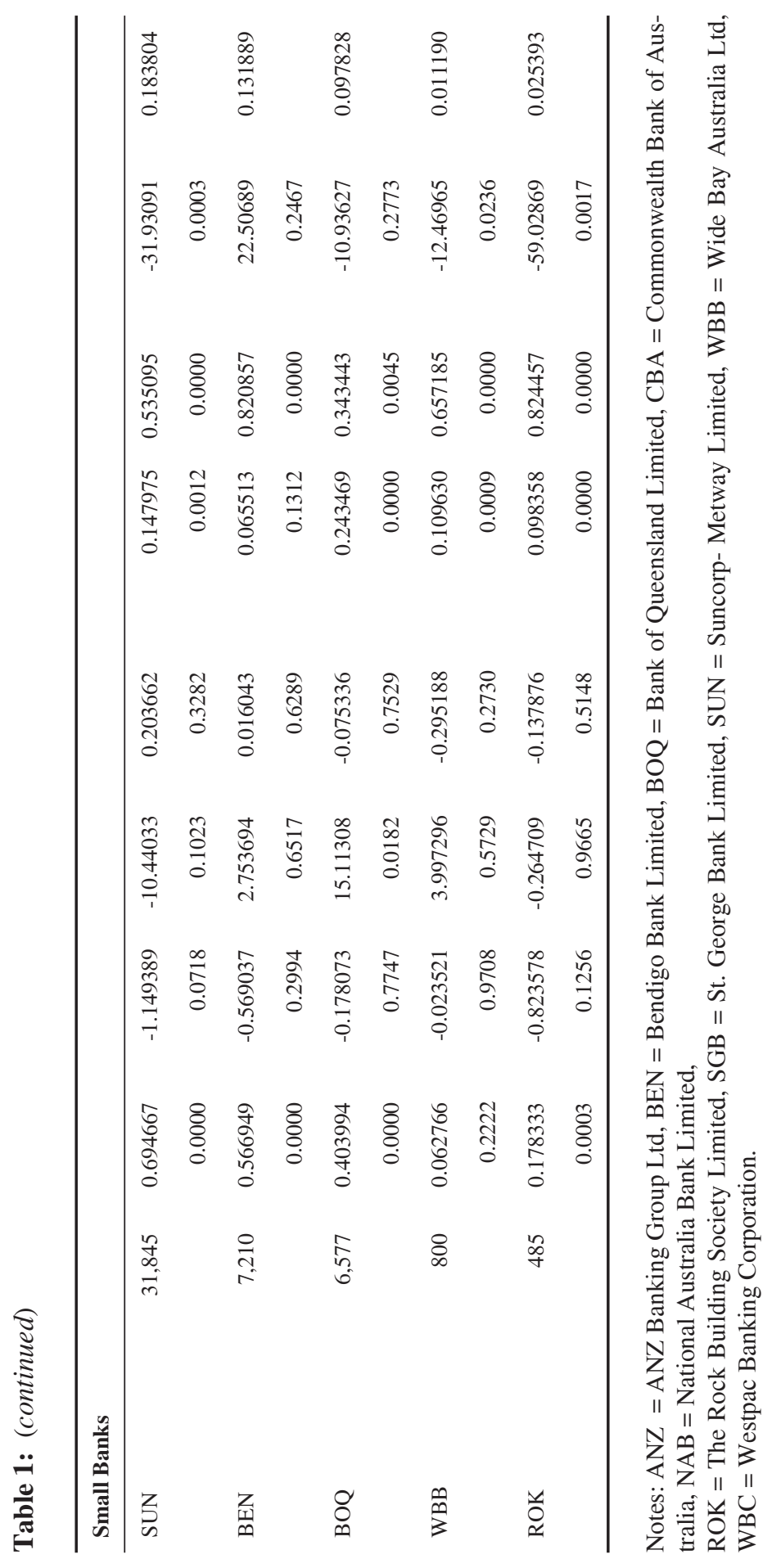




\section{References}

Akhigbe, A., and Whyte, A.M. (2003). Changes in market assessments of bank risk following the Riegle-Neal Act of 1994. Journal of Banking and Finance, 27, 87-102.

Atindéhou, R., and Gueyie, J. (2001). Canadian chartered banks' stock returns and exchange rate risk. Management Decision, 39 (4), 285-295.

Choi, J.J., Elyasiani, E., and Kopecky, K.J. (1992). The sensitivity of bank stock returns to market, interest and exchange rate risks. Journal of Banking and Finance, 16, 983-1004.

Dennis, S.A., and Jeffrey, A. (2002). Structural changes in Australian bank risk. Journal of International Financial Markets, Institutions and Money, 12, 1-17.

Daugaard, D., and Valentine, T. (1993). Bank share prices and profitability. School of Finance and Economics. Working Paper Series (No 31). University of Technology Sydney.

Elyasiani, E., and Mansur, I. (1998). Sensitivity of the bank stock returns distribution to changes in the level and volatility of interest rates: A GARCH-M Model. Journal of Banking and Finance, 22, 535-563

Faff, R.W., and Howard, P.F. (1999). Interest rate risk of Australian financial sector companies in a period of regulatory change. Pacific-Basin Finance Journal, 7, 83-101.

Harper, I.R., and Scheit, T. (1992). The effects of financial market deregulation on bank risk and profitability. Australian Economic Papers, 260-271.

Iorio, A.D., and Faff, R. (2000). An analysis of asymmetry in foreign currency exposure of the Australian equities market. Journal of Multinational Financial Management, 10, 133-159.

Loudon, G. (1993). The foreign exchange operating exposure of Australian stocks. Accounting and Finance, 32, 19-32.

Merrett, D.T. (2002). The internationalization of Australian banks. Journal of International Financial Markets, Institutions and Money, 12, 377-397.

Ryan, S., and Worthington, A. (2004). Market, interest rate and foreign exchange rate risk in Australian banking: A GARCH-M approach. International Journal of Applied Business and Economic Research, 2(2), 81-103.

Wetmore J.L., and Brick, J.R. (1994). Commercial bank risk: Market, interest rate, and foreign exchange. Journal of Financial Research, 17, 585-96.

Yong, H., and Faff, R. (2007). Asia-Pacific banks risk exposures: Pre and post the Asian financial crisis. Applied Financial Economics, 18(6), 431-449 